\title{
РОЛЬ МЕДИЧНОЇ СЕСТРИ У ЛІКУВАЛЬНО-ДІАГНОСТИЧНОМУ ПРОЦЕСІ ПРИ СЕЧОКАМ'ЯНІЙ ХВОРОБІ В УМОВАХ СТАЦІОНАРУ
}

\author{
О. Б. Сусла, І. П. Овсієнко \\ ДвНЗ «Тернопільський державний медичний університет \\ імені І. Я. Горбачевського МОЗ Украӥни»
}

Поширеність сечокам’яної хвороби в Україні займає друге місце серед всіх урологічних захворювань. Цей показник за останні 4 роки зріс у 1,2 раза; кількість хворих сягає понад 160000 осіб, зокрема 973 випадки на 100000 дорослого населення. Для того, щоб правильно встановити діагноз, пацієнту необхідно пройти комплекс лабораторних та інструментальних обстежень. Медична сестра повинна кваліфіковано допомагати лікарю в діагностиці і лікуванні зазначеної патології.

\section{ROLE OF THE NURSE IN TREATMENT AND DIAGNOSTIC PROCESSES OF UROLITHIASIS IN HOSPITAL CONDITIONS}

\author{
O. B. Susla, I. P. Ovsiyenko
}

\section{Horbachevsky Ternopil State Medical University}

The prevalence of urolithiasis in Ukraine ranks second place among all urological diseases. This index has increased by 1.2 times in the past 4 years. The number of patients exceeds 160000 persons, especially 973 cases per 100000 of the adult population. In order to determine the correct diagnosis, the patient should undergo complex of laboratory and instrumental examination. A nurse should promote skilfully assistance to the doctor in the diagnosis and treatment of this disorder.

Вступ. Сечокам'яна хвороба (уролітіаз) - це захворювання обмінного характеру, її виникненню передують різні біохімічні порушення в організмі. Такий стан у своєму розвитку потребує наявності відразу декількох причин та факторів, які в сукупності можуть бути тригером для розвитку патологічного процесу. Основною ознакою захворювання $є$ утворення і наявність поодиноких або множинних каменів у сечовій системі - чашечках, мисці, сечоводі, сечовому міхурі або уретрі $[1,3]$.

На сьогодні у світі від уролітіазу страждає 1-3 \% дорослого населення. Близько $12 \%$ чоловіків і $5 \%$ жінок протягом життя перенесли ниркову кольку. Хворі на сечокам'яну хворобу складають 30-40 \% усіх пацієнтів, які перебувають в урологічному стаціонарі. У США щорічно госпіталізовують понад 1 млн осіб із приводу утворення каменів у нирках і сечових шляхах. В Україні показник захворюваності на уролітіаз становить 460 випадків на 100000 населення. Від сечокам'яної хвороби страждають переважно особи чоловічої статі (2:1) зрілого і середнього віку [3, 4].

(с) О. Б. Сусла, І. П. Овсієнко, 2018
Основна частина. До факторів, що впливають на процес каменеутворення в сечовій системі відносять: 1) прийом незначної кількості рідини і виділення недостатньої кількості сечі; 2) перенасичення сечі солями сечової кислоти в зв'язку з їх надлишковою продукцією або виведенням, що супроводжується гіперурикозурією, гіперурикемією, при подагрі, мієлопроліферативних захворюваннях, псоріазі та ін.; 3) постійно виражена кисла реакція сечі з $\mathrm{pH}<5,5$ при хворобах травної системи, що супроводжуються проносами; 4) гіперпаратиреоз, інтоксикація вітамінами групи D; 5) дистальний нирковий канальцевий ацидоз; 6) інфекція нижніх сечових шляхів; 7) обструктивні процеси верхніх сечовивідних шляхів [1, 3].

В основу класифікації сечокам'яної хвороби закладені не лише причини їі виникнення та клінічні варіанти перебігу, а також основні характеристики каменів [3].

За складом компонентів, що входять до конкрементів, виділяють:

- камені неорганічного походження (кальцієві, кальцієво-оксалатні, кальцієво-фосфатні, магнієвмісні та ін.); 
- камені органічного походження (уратні, цистинові та ін.);

- змішані (полімінеральні).

За кількістю конкрементів в органах сечової системи:

- одиночний камінь (єдиний конкремент);

- множинні камені;

- коралоподібний конкремент.

За локалізацією процесу:

- камені (або камінь) в чашечках нирок;

- камінь, локалізований на різних ділянках сечовода (верхній, середній або нижній третині);

- камінь у просвіті сечового міхура;

- камінь в уретрі.

За причинами виникнення:

- первинний уролітіаз (вперше діагностований);

- рецидивний уролітіаз (формування нових каменів);

- резидуальний уролітіаз (наявність у хворого конкрементів, що не піддаються ефективному лікуванню).

За характером перебігу:

- неінфікований;

- інфікований.

Симптоми сечокам'яної хвороби, як правило, виникають в момент просування сформованого каменя по сечовій системі [1]. Для патологічного стану характерною $є$ тріада клінічних проявів:

- больові відчуття різного ступеня вираження;

- зміни в сечовому осаді (наявність крові, гною та інших компонентів);

- порушення процесу виділення сечі, аж до повної анурії.

Діагностика уролітіазу неможлива без ретельно зібраного анамнезу. Особливу увагу приділяють усім факторам ризику, що можуть бути тригером початку захворювання [3]. При огляді визначають ділянку найбільшого ураження, а також інші патологічні симптоми, що характерні для патологічного процесу (напруження м'язів передньої черевної стінки, позитивний симптом постукування в поперековій ділянці та ін.). Усім пацієнтам із уролітіазом необхідно пройти такі лабораторні дослідження [2]:

- загальний аналіз крові;

- загальний аналіз сечі;

- біохімічне дослідження крові;

- вміст білка з добової кількості;

- бактеріологічне дослідження сечі.

Усі пацієнти з підозрою на сечокам'яну хворобу в умовах стаціонару піддаються таким інструментальним обстеженням, як [2, 3]:
- оглядова рентгенографія живота з візуалізацією ділянки проекції нирок, сечоводів і сечового міхура (діагностика рентгенопозитивних конкрементів);

- екскреторна (внутрішньовенна) урографія (оцінка анатомії та функціонального стану сечової системи);

- ультразвукове дослідження нирок (візуалізація всіх структур органа, а саме положення і розмірів нирок, паренхіми, стану чашково-мискового апарату, наявності каменів, гнійників або інших патологічних утворень);

- комп'ютерна або магнітно-резонансна томографія нирок (характеризується високою інформативністю, особливо у випадках, якщо камінь не було виявлено при інших інструментальних дослідженнях).

Варто відзначити, що важливою умовою ефективності лікувально-діагностичного процесу при сечокам'яній хворобі $є$ правильна організація роботи середнього медичного персоналу урологічного відділення $[2,4]$. Медична сестра повинна знати, який матеріал варто збирати для лабораторних аналізів та вміти:

- пояснити пацієнту мету лабораторного дослідження і отримати згоду на його проведення;

- провести інструктаж із пацієнтом щодо підготовки до обстеження і методики забору матеріалу (у випадку самостійного забору);

- підготувати необхідну кількість ємностей та інструментарію;

- заповнити направлення з визначенням профілю лабораторії, мети дослідження;

- своєчасно відправити біологічні матеріали на дослідження;

- своєчасно отримати результати лабораторної діагностики з фіксацією їх у медичній документації.

Достовірність та інформативність результатів інструментальних методів дослідження значною мірою залежать від якості підготовки хворих до цих маніпуляцій [4]. Зокрема, для проведення оглядової рентгенографії нирок протягом 2-3 діб виключають із раціону продукти, що викликають підвищене газоутворення в кишечнику, не призначають проносних засобів і медикаментів, що містять йод. Напередодні дослідження о 22 год роблять очисну клізму. В день обстеження хворі не споживають їжу і рідину. Вранці за 3 год до процедури знову роблять очисну клізму. Безпосередньо перед процедурою хворий звільняє сечовий міхур. Якщо ж виявляють значну кількість газу в кишечнику, знову його очищають і через 45 хв після очисної клізми виконують рентгенографію [4]. 
Висновки. Своєчасна і правильна діагностика сечокам'яної хвороби вумовах стаціонару значною мірою залежить від ефективної роботи медичної сестри, ії професійних компетентностей. Рання діагностика

\section{СПИСОК ЛІТЕРАТУРИ}

1. Воробцов В. И. Камни почек и мочеточников / В. И. Воробцов. - М. : Медицина, 2009. - 184 с.

2. Дзеранов Н. К. Лечение мочекаменной болезни комплексная медицинская проблема / Н. К. Дзеранов // Урология. - 2004. - С. 18-24. уролітіазу визначає тактику ведення таких пацієнтів, характер консервативного лікування, перебіг до- та післяопераційного періодів.

3. Колпаков И. С. Мочекаменная болезнь : руководство для врачей / И. С. Колпаков. - К. : Полиграф Плюс, 2014. - 117 c.

4. Протоколи медичної сестри (фельдшера, акушерки) з догляду за пацієнтом і виконання основних медичних процедур та маніпуляцій / М. К. Хобзей, Т. І. Чернишенко, В. Г. Апшай [та ін.]. - К. : ВСВ «Медицина», 2015.

Отримано 11.01.18 